\title{
Education as an institution of national identity formation
}

\author{
Oleg F. Shabrov ${ }^{1 *}$, Natalia P. Sashchenko ${ }^{2}$, and Museib Hayat ${ }^{1}$ \\ ${ }^{1}$ Lomonosov Moscow State University, Faculty of Political Science, Department of Public Policy, \\ Moscow, Russia \\ ${ }^{2}$ Institute for Social and Political Research, Federal Research Sociological Center, Russian Academy \\ of Scinces, Center for Social Security and Riskology, Moscow, Russia
}

\begin{abstract}
The article touches upon the problem of the crisis of nationalstate identity of young Russian citizens. Digitalization fundamentally changes the functioning and reproduction of the culture, which underlies group, ethnic, national, and state identity. These changes may cause significant risks of destabilizing the state and its main institutions. The authors discuss the role of educational institutions in the reproduction and formation of new social values among young people and the following formation of the national-state identity. The empirical part of the study is aimed to identify the basis of national-state identity, which is the structure and content of social ideas about Russia among various groups of users of social networks aged 14-35 years, selected according to their gender, age, and educational background. The article presents the results of the empirical study of respondents' social representations about Russia. It explains the correlation between the national-state identity and social representations of one's country and indicates the structural-functional and contentmorphological characteristics of the social ideas of young people about Russia. It also reveals the differences in the social representations of young people from different population groups. The results make it possible to clarify the understanding of the pattern of Russian young people's social thinking, which is responsible for the choice of identification images and predetermines the strength and direction of political attitudes that affect the political stability of Russia.
\end{abstract}

Keywords: education system, social representations, identity.

\section{Introduction}

The problem of national-state identity is one of the most important among the problems that humanity faces in the 21 st century. There are many reasons for this, which were carefully examined by F. Fukuyama [1] and several Russian political scientists, such as V.A. Achkasov [2], R.V. Evstifeev [3], and others. The events of recent years have clearly shown the urgency of this problem. The scale of mass migration, cross-border communication, and the impact of global players on peoples' national identity using the soft power strategy negatively affected the loyalty of many countries' citizens to common values, forming the basis of

\footnotetext{
* Corresponding author: oshabr@mail.ru
} 
identity and the cohesion among the population in their states. Interracial, interethnic, and interreligious clashes in Europe and the United States have called into question the ability of state institutions to rely on the support of civil society. There is no reason to believe that these conflicts are temporary. The organizers of the Black Lives Matter movement in the US are convinced that "getting Trump out of office was not the end all, be all. The work is just beginning" [4].

The formation of national-state identity is a complex and multifaceted process, which involves different institutions. One of the most important is the educational institution, through which the state has the opportunity and is obliged to pursue a targeted policy in the field of identity, relying on both traditional values and ideological constructs. The interpretation of historical facts and assessment of the activities of historical figures are of particular importance.

The experience of today's Ukraine is a well-known example of the construction of a new identity. The Ukrainian political elite, which proclaimed independence, inevitably had to detach itself from the symbolic list associated with the history of the Soviet Union and Russia, create new heroic events and heroes, and oppose a new image of "us" to the image of "them" represented by Russia. Since school years, Ukrainian children learn heroic events of the struggle of the Directorate of Ukraine for independence and the activities of S. Bandera, I. Mazepa, and S. Petliura, who called Ukrainians to fight "our worst enemy: Moscow" [5].

The new possibilities for managing mass consciousness have appeared in Russia as well. The main object of influence is the consciousness of the masses, which is formed through the mechanisms of transformation of social representations. The transformation is possible due to perceptions' speculation, uncertainty, and remoteness [6: 91], creating prerequisites for instability, uncertainty of a person.

\subsection{Theoretical literature review}

There is a growing concern of scientists about the techno-humanitarian imbalance [7], the increasing gap between technological optimism and social pessimism [8: 16, 35;9], the emergence of global risks and "exacerbation regimes" [10], and the vulnerability of humanitarian technologies and management systems in a risk society [11]. One of the consequences of these changes is the crisis of national-state identity [12-14] in many countries, including Russia.

Concern about the socio-political instability in Europe as a result of the loss of national identity by citizens appeared in studies devoted to the dependence of social representations about threats and risks on socio-political and cultural contexts [15-18]. The study of the interconnection between culture and social thinking $[19 ; 20]$, cultural diversity, social identity, and cohesion among the population [21] are of particular importance.

Educational institutions performing two main functions (teaching and socialization become more and more important. The latter function includes the formation of citizens with national identity, who are ready to support their state for the sake of the common good [22].

Educational institutions provide either the development or degradation of society regardless of the wishes of the political elites. If the main function of the political subsystem is goal-setting and the organization of goal-achievement [23: 24], then educational institutions form a person who is going to participate in achieving this goal and function in a future designed according to this goal. Value models, instilled with knowledge, form a valueconceptual matrix of the socio-political system. They will become the basis for the identity of the future person, as well as their attitude towards the country and the state.

The aforementioned works set the following tasks for educational institutes: to reconstruct the value-conceptual matrix for better identification of citizens with a given socio-political system; to increase the role of the educational process in acquiring not only 
knowledge but also values and meanings [24: 310;25:22]. The need for the transformation of the image of education, associated with the interconnection between the socio-political system and the value-conceptual matrix [26: 9], is also justified.

\subsection{Hypothesis}

As a result of the Russian education system, the core of the social representation of Russia by young people is contradictory, which may become a reason for the blurred national-state identity.

\subsection{Aim}

The study is aimed to identify the system of images and symbols associated with the concept of Russia in the minds of young people and social representations within the theory of "coreperiphery".

\section{Methods}

Political sociology, political psychology, and social psychology theories are of significant theoretical and methodological significance for the study of national-state identity in general and the identity images of the country in particular. They are also important for the identification of the semantic framework of the perception of social reality, as well as emerging frames and narratives of collective memory responsible for the direction for changes and stability of national-state identity [27-29].

The following research methods were used in the study: an online survey of social media users; the method of free associations developed by J.-C. Abric [30], aimed to identify social representations; content analysis of statements of qualitative and quantitative modification; the method of prototypical and categorical analysis developed by P. Verges [31].

\section{Results and discussion}

The study of the structure and content of social representations of the young people about Russia (users of Facebook and VKontakte) was carried out in June 2020. A total of 2,035 associations were received.

In general, the consciousness of "digitalized" young people is characterized by inconsistency, a certain blur, and instability. In the structure of the received social representations, the core is formed by those ideas, which reflect the collective memory of the youth, stable and shared by the majority of the group. The central core contains a limited number of elements that give meaning to the perception. These central elements are defined as consensual and undeniable [32-34]. The peripheral system depends on the central core and is of the greatest density; it is the most accessible and flexible part of social representations.

According to our results, the core of social representations about Russia is represented by three concepts ("country", "home", "pride") with the same average frequency in the lists. The frequency is higher for the concept of "country". Besides, among other concepts, "country" is associated with different meanings and has different connotations. The clustering of associations into concepts showed that "country" is perceived in two ways: as a territory and as a home. The characteristics of the country as a territory fell into zones 2 and 3, which are zones of potential changes. They specify the elements of the first zone of the core. These zones include such characteristics as "huge", "big", "resources", "potential", "opportunities", 
"strength", "love", and "power". In the core zone, in addition to the concept of "country", the concepts of "home" and "pride" reflected a warm, reverent attitude towards the country, with a sense of pride for its achievements. Speaking about all concepts, the associations "Russia-country" and "Russia-state" are represented almost equally, with positive and negative connotations at the same time ("country of opportunities", "rich country", but "state" dominated by "decline", "devastation", and "corruption"). Such concepts as "homeland", "great", "Putin", and "state" are present in young people's representations of Russia and are of high frequency. Yet, their frequency does not allow us to say that "homeland" and "state" are the key elements around which the respondents' representation of Russia is formed. These concepts did not enter the core zone but entered the first one, which is the zone of potential changes.

The following concepts were also included in the first peripheral system that makes up a potential zone of change: "place", "native", "family", "life", "future", "fear", "corruption", "history", "stagnation", and "deep end". The concepts are sorted in descending order of frequency. This zone also includes associations with sensory categories. The emotional tone is reduced, feelings of anxiety, disappointment, fear, anger, powerlessness, indifference, and hopelessness appear. However, this zone is not stable; it is contradictory and sensitive to the actual context of its existence, performing the functions of adaptation to modern life and protection of the core.

The expansion of the identity zone to the global one is possible, but $\mathrm{s}$ associated with the problem of balancing the global and the national-state identities. The study of the problem of preserving the national-state identity and the cultural code of the country [35] in the context of the expansion of the identity zone to the global one becomes relevant. Yet, it would give a more constructive result when turning to the main methodological approaches to the study of personality in the space of identification processes: symbolic interactionism, behaviourism, cognitive and constructivist approaches.

\section{References}

1. F. Fukuyama, Identity: the demand for idgnity and the politics of resentment (Farrar, Straus \& Giroux, New York, 2018)

2. V.A. Achkasov, Vestnik Moskovskogo Universiteta. Series 12, Political Science, 4, 63-67 (2010)

3. R.V. Evstifeev, POLITEX, 15(1), 108-121 (2019)

4. Black Lives Matter. Join Black Lives Matter in our request for a meeting with President-elect Biden and Vice President-elect Harris (2020). Accessed on: November 15, 2020. [Online]. Available: https://blacklivesmatter.com/join-black-lives-matter-inour-request-for-a-meeting-with-president-elect-biden-and-vice-president-elect-harris

5. V.S. Vlasov (Ed.), Istoriya Ukrainy: uchebnik dlya 10 klassa uchrezhdenii obshchego srednego obr. [History of Ukraine. A textbook for students of the tenth year of general secondary education institutions] (Litera LTD, Kiev, 2018)

6. K.A. Abulkhanova, Sotsialnoe myshlenie lichnosti [Social thinking of a person], in Sovremennaya psikhologiya: sostoyanie i perspektivy issledovanii. Chast 3. Sotsialnye predstavleniya i myshlenie lichnosti [Modern psychology: the current state and research prospects. Part 3. Social representations and thinking of a person], 88-103 (Publishing House "Institute of Psychology of the Russian Academy of Sciences", Moscow, 2002)

7. A.P. Nazaretyan, Tsivilizatsionnye krizisy v kontekste Universalnoi istorii [Civilization crises in the context of Big History] (Per Se, Moscow, 2001) 
8. T.A. Nestik, A.L. Zhuravlev, Psikhologiya globalnykh riskov [Psychology of global risks] (Publishing House "Institute of Psychology of the Russian Academy of Sciences", Moscow, 2018)

9. A.L. Zhuravlev, T.A. Nestik, Psychological Journal, 40(5), 35-47 (2019)

10. E.N. Knyazeva, S.P. Kurdyumov, Osnovaniya sinergetiki. Rezhimy s obostreniem, samoorganizatsiya, tempomiry [Foundations of synergetics: blow-up regimes, selforganization, tempoworlds] (Aletheia, Saint Petersburg, 2002)

11. G.G. Malinetskii, Strategiya Grazhdanskoi Zashchity: Problemy i Issledovaniya, 2, 1517 (2013)

12. T.V. Evgeneva, Tsennosti i Smysly, 5(21), 27-36. (2012)

13. O.I. Zaznaev, Natsionalno-gosudarstvennaya identichnost: zarubezhnyi opyt i Rossiya [National-state identity: foreign experience and Russia], in Politicheskaya identichnost i politika identichnosti: ocherki [Political identity and identity politics: essays], 6 (Publishing House "Otechestvo", Kazan, 2011)

14. N.P. Sashchenko, Transformatsiya sotsialno-politicheskikh predstavlenii: problema natsionalno-gosudarstvennoi identichnosti [Transformation of socio-political views: the problem of national-state identity], in Pcoceedings of the Conference "Pandemiya kak dvigatel transformatsii: globalnoe, gosudarstvennoe i korporativnoe upravlenie [Pandemic as a driving force for transformation: global, state and corporate management]", 25-26 May 2020, Moscow, Russia, 28-32 (2020)

15. J.C. Etoundia, N. Kaya, S. Gaymarda, Journal of Social and Political Psychology, 8(2), 642-661 (2020). https://doi.org/10.5964/jspp.v8i2.1218

16. S. Gaymard, Psychology of Language and Communication, 16, 185-200 (2012). https://doi.org/10.2478/v10057-012-0013-9

17. S. Gaymard, N. Kay, J. C. Etoundi, Canadian Social Science, 11(7), 53-64 (2015). https://doi.org/10.3968/7273

18. H. Joffe, British Journal of Social Psychology, 42, 55-73 (2003). https://doi.org/10.1348/014466603763276126

19. R. Jaspal, B. Nerlich, M. Cinnirella, Environmental Communication, 8(1), 110-130 (2014). https://doi.org/10.1080/17524032.2013.846270

20. R. Kmiec, C. Roland-Lévy, Les Cahiers Internationaux de Psychologie Sociale, 101, 69-99 (2014). https://doi.org/10.3917/cips.101.0069

21. F. Pigeaud, Au Cameroun de Paul Biya [In Paul Biya's Cameroon] (Karthala, Paris, France, 2011)

22. O.F. Shabrov, Institut obrazovaniya i natsionalno-gosudarstvennyi suverenitet Rossii [Education Institute and the National State Sovereignty of Russia], in Proceedings of the 8th All-Russian Congress of Political Scientists "Politika razvitiya, gosudarstvo i mirovoi poryadok [Development Policy, State and World Order]", 6-8 December 2018, Moscow, Russia, 573-574 (2018)

23. T. Parsons, Sistema sovremennykh obshchestv [The system of modern societies] (Publishing House "Aspect Press", Moscow, 1997)

24. D. Easton, The School Review, 65(3), 304-316 (1957)

25. C. Gaohua, Journal of Educational Science of Hunan Normal University, 3, 20-25 (2017)

26. A.G. Meyer, Economics of Education Review, 56, 9-23 (2017)

27. L.M. Drobizheva, Sociological Research, 8, 37-50 (2020) 
28. T.V. Evgeneva, Identifikatsionnoe izmerenie obraza strany: metody issledovaniya $i$ interpretatsiya rezultatov [Identification dimension of the country's image: research methods and results interpretation], in Proceedings of the 9th International Sociological Conference "Sotsialnaya Inzheneriya: Kak Sotsiologiya Menyaet Mir [Social Engineering: How Sociology Changes the World]", 20-21 March 2019, Moscow, Russia, 188-193 (2019)

29. S. Moscovici, La psychanalyse, son image et son public: Etude sur la représentation sociale de la psychanalyse [Psychoanalysis, its image and audience: Study of the social representation of psychoanalysis] (PUF, Paris, France, 1961)

30. J.-C. Abric, La recherche du noyau central et de la zone muette des représentations sociales [The search for the central core and the silent zone of social representations] (Érès, Toulouse, 2003)

31. P. Verges, Textessur les representations sociales, 3(1), 3-12 (1994)

32. J.-C. Abric, Jeux, conflits et représentations sociales [Games, conflicts and social representations] (Unpublished doctoral dissertation) (Aix-Marseille University, Marseille, 1976)

33. C. Flament, Structure, dynamique et transformation des représentations sociales [Structure, dynamics and transformation of social representations], in J.C. Abric (Ed.), Pratiques sociales et représentations [Social practices and representations], 37-57 (PUF, Paris, France, 1994)

34. P. Moliner, La représentation sociale comme grille de lecture. Étude expérimentale de sa structure et aperçu sur ses processus de transformation [Social representation as a reading grid: Experimental study of its structure and overview of its transformation processes] (Unpublished doctoral dissertation) (Aix-Marseille University, Marseille, 1988)

35. Zh.M. Grishchenko, Yu.G. Sivertsev, Nauka. Kultura. Obshchestvo, 2, 45-52 (2020) 